\title{
Imagology of Iranians in One Thousand Nights and One Night
}

\author{
Ehsan Ghabool \\ Assistant Professor of Ferdowsi University of Mashhad, Iran \\ ghabool@ferdowsi. um. ac. ir \\ Mina Ravansalar \\ Translator and Researcher \\ ravansalar@gmail.com
}

\begin{abstract}
Imagology is a branch of comparative literature which explores the image of one nation in the literature of another nation. One Thousand Nights and One Night is among the important books which can show the image of different nations and people such as Indians, Iranians and Arabs. Since the oldest version of the book is in Arabic, it is considered an Arabic literary work though it was translated from a Persian tale in the first place. On this basis the study of the image of Iranians in One Thousand Nights and One Night can be included under the definition of imagology. In this article, first we explain, analyze and study the image of Iranians in the book One Thousand Nights and One Night with respect to 1. anthropology (including entertainments, personification of animals, disapprobation of lies and betrayal of spouses), 2. religious and mythical beliefs (including the belief in daevas and jinnis, magic, fire-worshipping and similar plots), 3. politics (emphasizing the position of vizier and his family in government), 4. economics (emphasizing economic prosperity), then we will compare the collected information with the image of Iranians in credited works and in this way we will identify the similarities and differences of Iranians' image in One Thousand Nights and One Night and the above-said literary works. Finally we come to this conclusion that the similarities belong to the real image of Iranians in the pre-Islamic days and that differences show the image of post-Islamic Iran which is added through Arabic translation.
\end{abstract}

Keywords: Imagology, Iranians, One Thousand and One Night, Comparative Literature

\section{Introduction}

Imagology is a sub-branch of comparative literature which was developed after the methodical teachings of comparative literature in French in the course of the nineteenth century under the impact of philosophers like Madame de Staël and Hippolyte Taine. Imagology has an Interdisciplinary approach and applies known branches of knowledge such as literary history, political history, social psychology and semi-modern branches such as aesthetics and semiotics. Imagology is about the study of the image of "the other" in literature or art, in other words Imagology is the knowledge and method to study the image of foreign countries and characters in the works of an author or an era. This knowledge defines the main property of an image as the difference between an "l" and an "other" and between "here" and "there" (Nanquette, 1390:107). Imagology is mainly involved with two texts: travelogues and narrative literary works in which the characters are foreigners or represent a general image of a foreign country (Moura, 1980: 35).

One Thousand Nights and One Night is a narrative which was created in the Indian and Iranian mindset before Achaemenid Empire. It was translated from Middle Persian to Arabic in the ninth century and some stories were added to the translation 
from the Arabian setting and culture and some stories underwent changes considering their time, place ${ }^{1}$ and content ${ }^{2}$ (Rypka, 1370:123). Nevertheless the oldest accessible copy of One Thousand and One Nights is in Arabic; therefore in the list of the books on history of literature this work is included in Arabic Literature ${ }^{3}$.

On this basis, one of the important and new issues about One Thousand and One nights is to identify the image of Iranians in it (the subject of this article has not been discussed before. ) and the other is to find out which of these images are the product of Arab mentality about Iranians and which are compatible with the historical and social facts about Iranians ${ }^{4}$. To answer these questions we are going to describe, classify and analyze the image of Iranians in the (first volume of the) book The thousand and One Nights from several aspects such as anthropology, politics, economics and religion and then identify the image of Iranians in pre-Islamic days through major books written in that era or the books written based on the works created then such as the History of Herodotus, pre-Islamic literary works, Ferdowsi's Shahnameh (book of kings), et al. Finally, comparing the images of the Iranians found in One Thousand and One Nights and other works, we will explore the similarities and differences between these images.

\section{The Image of Iranians in One Thousand Nights and One Night and Some Pre-Islamic Works}

The word Iran means "the land of Aryans" and Aryans were the people who immigrated from the Middle Asia about 2000 BC. A group of the Aryans who are called Indo-Iranian settled in India and a group settled in Plateau of Iran; but the racial and cultural commonalities shared between these two groups were very deep-rooted and profound, one of the most important of which is common myths (Haririan, 1383:59-60). Therefore it is important to consider the 12000-year-long Iranian mythological history - a part of which is common with India- to identify the image of Iranians in One Thousand and One Nights. Also it is important to take into consideration the historical works in which Iranians are observed directly and therefore described and introduced. The oldest book on this issue is History of Herodotus created in $5^{\text {th }}$ century BC.

\section{1. Anthropology}

By anthropology we mean understanding factors such as set of customs and habits, dreams and superstitious beliefs and social hierarchy of different groups of people of Iran. Here we deal with three images of Iranians mentioned in One Thousand Nights and One Night.

\section{1. 1. Entertainments}

One of the main motifs of the tales of One Thousand Nights and One Night is dealing with entertainments and games; entertainments and games such as riding, archery, polo, hunting and drinking. We see that Shahryār and Shāhzamān, two main characters of the book, are champions of riding. (This subject is not mentioned in the Persian translation directly but in Arabic and English texts their championship is mentioned. ) And when Shahryār found that Shāhzamān is not in a good

\footnotetext{
1 The mixture of times, locations and characters is obvious in One Thousand Nights and One Night stories; we see that Scheherazade lives in Sassanid's period in pre-Islamic era but narrates stories from Islamic caliphate period or in a story a person named King Fereidoon is introduced as the Greek king (p. 265) while Fereidoon was a name of Iranian kings (Ferdowsi, Volume 1, 1374: 79). This time and location clutter can be considered as the result of the parts added by Arab translators; but the important point is that some preIslamic Iranian characters and factors are mentioned in the stories of Islamic period such as king Fereidoon; therefore such stories can be studied in the settings of Iranian stories.

${ }^{2}$ Among the changes found in One Thousand Nights and One Night is the usage of hashish to make someone go asleep which cannot be an old habit among Iranians in pre-Islamic era or even primary Islamic centuries, and that it is a result of its translation during next centuries (Safa, volume 1/5, 1378:121).

3 The stories of One Thousand Nights and One Night can be classified based on their location like Iranian, Arabic, Egyptian, Greek, Roman, Indian and Chinese stories. Considering the fact that the setting of the frame story in Iran and between Scheherazade and Shahryār, it can be said that whenever the setting of the story is vague, the story generally belongs to the original part of One Thousand Nights and One Night and the same Iranian period. From another point of view the tales of One Thousand Nights and One Night can be divided into three parts: main part derived from Middle Persian literature and next two parts from Baqdad and Egypt (article of E.

Littmann in Islamic encyclopedia, volume 1) (qouted by Safa, 1/5 1378:121)
}

${ }^{4}$ See: Fakhuri, 1389: 534, Abd Al-Jalil, 1382:251 
mood suggests him to go hunting so that exhilaration may appear in his heart (p. 3)1. In the story "king Sindbād" in the tale of sixth night, we see that the main subject of the story is about one of Persian kings who love recreation and hunting. It is significant to consider recreation and hunting the same (p. 31) or a king who goes hunting for several days (p. 67). In another story polo is mentioned as one of the recreations of kings (p. 28). Drinking is also another dominant image in the Iranian stories of One Thousand Nights and One Night for example wining and dining of Shāhzamān (p. 5) or drinking of a prince with his cousin for joy and happiness (p. 63).

Herodotus, the famous Greek historian, who traveled to Iran and studied and researched about its people writes: "They only teaches three things to their children of the age 5 to 20 and those three things are: riding, archery and telling the truth. " (Herodotus, 1383: 219). Therefore riding and archery were the primary education of each Iranian child and youth. The game polo is also one of the sports of ancient Iran and its history goes back to $600 \mathrm{BC}$ and is mentioned in the book of Ardashir-e Bābakān (also known as Ardashir I or Ardashir the Unifier), Karnameh belonging to late Sassanid period (Tafazoli, 1376: 261) and in many stories of Shahnameh a part of noblemen's recreation and entertainment was hunting and polo. It is obvious that in hunting, archery, riding and polo riding a horse and aiming plays the main role. Dinking also had an important place among the ancient Iranians; in the book Menog-i Khrad (meaning: "Spirit of Wisdom") it is written that the nature of good and bad is revealed by wine but one should be conscious in drinking it (Yahaghi, 1386: 800), Herodotus also states that the Persian loves wine (Herodotus, 1383:217) and in the stories of Shahnameh one of the main acts during feasts and parties was drinking. Therefore we can conclude that the collection of the entertainments attributed to Iranians in One Thousand Night and One Night is in accordance with their historical and cultural background.

\section{1. 2. Personification of Animals}

One of the features in The Thousand Nights and One Night is that human qualities and characters are given to animals and in the tales where animals are personified prescriptions and advices are more common; an example of this, is the "Fable of birds" which Shahryār believes has increased his piety and virtue (p. 509) therefore asks Scheherazade to narrate more such tales and Scheherazade narrates several animal fables afterward (ps. 498-528).

Ibn al-Nadim writes: "the first people who wrote legends, compiled them in a book, kept them in their treasure houses and narrated some of them through animals' speech were the primitive Iranians (the Achaemenian and the Kianian). After Achaemenian the Parthian kings, of the second Iranian empire, expanded this issue and then at the time of the Sassanid the number of tales increased and Arabs translated them into Arabic. " (Ibn al-Nadim, 1352: 363. ) In Shahnameh a number of Houshang's army are the animals and Simurgh has human characteristics. Also Kalïlah wa Dimnah which has a background as same as The One Thousand Nights and One Night is an animal fable. The book Draxt i Āsūrīg (meaning "The Assyrian Tree" or "The Babylonian Tree") belonging to pre-Islamic Iran is also a dialogue between a goat and a palm tree (Tafazoli, 1378: 256-259).

Therefore it can be concluded that personification was a characteristics of Iranians which appeared in The Thousand Nights and One Night tales. Iranian used animal personification mostly when they intended to express subject matters such as philosophy and advice; because advices are more effective when expressed indirectly; also since the audiences of these advices are usually the kings and the authorities, expressing them from animals would observe their respect, moreover, the public tendency of Iranian thoughts is to express the concepts symbolically so we see that in the animal fables the manner and speech of each animal symbolizes a person or concept.

\section{1. 3. Disapprobation of Lies}

Lying is highly abominable and bad in the tales of One Thousand Nights and One Night and in all the tales the spirit of honesty is found; for example we read in a tale that a slave lies once a year and his master though knows about this bad feature buys him, but when he is confronted with his lie and its evil consequent, cuts the slave's penis and considers this characteristics very harmful (p. 249) or in another story it is said "tell the truth as the rescue is in honesty and avoid lying as the liars are the losers" (p. 270) and if any lie or false speech is uttered it is from quite negative and black characters and these people have negative characteristics such as the Wazir (vizier) who is stingy and vicious and falsely accuses

${ }^{1}$ For avoiding repeated references, references to One Thousand Nights and One Night are mentioned as the page number only. 
the doctor (p. 30) or the sinful friends of the slave who tells a lie once a year call him "Palīd ibn-e Palīd" (meaning a filthy person whose father is also filthy) (p. 249). Also in a symbolic story animals are speaking to a lion cub and mention the human being as the cause of ruse, evil and oppression and finally this is the human who plays ruse and captivates the lion and burns it to death (p. 498-503).

We mentioned that according to Herodotus one of the three characteristics which Iranian teach their children and is important to them is honesty (Herodotus, 1383: 219). In Shahnameh in the story "Esfandiyār's seven labours" when Gorgsar tells a lie to Esfandiyār, he reproofs him at first and finally kills him (Ferdowsi, Volume 6, 1374: 184-191). Mitokht daeva who is the symbol of skepticism and falsehood, is the first creature of false gods and is in contrast with the god of good words, Mārspand (Haririan, 1383: 83 \&87). On this basis we conclude that disapprobation of lies and the spirit of honesty ruling the tales of One Thousand Nights and One Night roots from Iranian History and thought.

\section{1. 4. Betrayal of Spouses}

The stories of the book The Thousand Nights and One Night take place during the Sassanid period. King Shahryār and his brother king Shahzamān are betrayed by their wives and this theme of betrayal circulates in other stories as well (ps. 3, 5, 6 and 21). There are a few examples of betrayal in pre-Islamic Iranian stories such as Vis and Rāmin, but in the most famous story of Sassanid period, Khosrow and Shirin, we see that when Shiroyeh murders his father, Khosrow, and intends to marry his stepmother, Shirin, she avoids him and stays continent and loyal to her deceased husband by killing herself (see: Ferdowsi, volume 9, 1374: 284-292 and Khosrow and Shirin by Nizami Ganjavi, 1381: 271-274) or the famous story Soodabeh and Siyavash in which Soodabeh, Siyavash's stepmother, tries to seduce him but Siyavash avoids her and does not betray (Ibid, volume 3, 1374: 14-23); But betrayal is found more repeatedly in Pre-Islamic Arabic literature; for example in the most famous poetry collection of this era, The Seven Mu'allaqāt (meaning The Suspended Odes or The Hanging Poems) consisted of seven long poems, we are confronted with several betrayals in the first poem composed by Imru' alQais'. On the same way the theme, betrayal is found repeatedly in the Arabic stories of The Thousand Nights and One Night (ps. 46,179,184, 205, 246 and 249). Therefore it can be said that the issue of spouses' betrayal in the Iranian court is not based on the reality of their image and it was exaggerated in the post-Islamic translations.

\section{2. Religious and Mythical Beliefs}

Religious and mythical features refer to Iranian beliefs. Here we mention four of them in One Thousand Nights and One Night.

\section{2. 1. Believing in Daeva and Jinnis}

In the mythical history of Iran, daevas are supernatural entities with disagreeable characteristics and some of these daevas described in Avesta and other Pahlavi books functions as the Ifrits and jinnis mentioned in The One Thousand Nights and One Night; for example "Varun" is the daeva of unnatural lust, "Āz" is the daeva of avarice and greed, "Rashk" is the daeva of hatred and the evil eye, "Mithaokhta" is the symbol of skepticism and falsehood (Haririan, 1383: 59-60). In the stories of the ancient Persia the presence of these daevas are obvious; for example in the stories of the mythical part of Shahnameh we can see these daevas like Siamak is killed by the evils and daevas and Houshang, son of Siamak fights against the daevas' army (Ferdowsi, volume 1, 1374: 30-32).

One of the outstanding issues related to Iranians in One Thousand Nights and One Night is the presence of jinnis, daevas and Ifrits who are mostly negative like the Ifrit who abducts a bride from her bridegroom in the first night of their marriage (p. 6, 69). This Ifrit is similar to Varun daeva in Iranian myths. On this basis the presence of these jinnis and daevas in the stories of One Thousand Nights and One Night can be considered in accordance with the Iranian believes. On the other hand we see the fairies who are positive creatures like the fairy that saves the old man in the story of old man and his two dogs and transforms his two brothers who betrayed him into dogs (ps. 19-20) or the snail that after being saved by a girl, introduces himself a fairy and returns the properties of the girl to her and enchants her sisters into two dogs (p. 90). The point which should be considered here is that when the stories happen in the setting of Arabic cities or at the time of Abbasid

\footnotetext{
1 See: The Seven Mu'allaqāt: Imru' al-Qais's poem.
} 
Caliphate the presence of ifrīts, fairies and magic is very few or none like the long stories Nūr Al-Dīn and Shams Al- Dīn (ps. 102-137), the tale of hunchback with the tailor, the Christian broker, the steward and the Jewish (ps. 137-207) or the tale of two vizier and Anis Al-Jalis (ps. 208-242) and the long tale of King Umar Al-Numān and hid two remarkable sons, Sharkān an Dū Al-Makān.

\section{2. 2. Believing in Magic}

One of the main events in the stories of One Thousand Nights and One Night is magic, as the several magic we see in the story of old man and the beast (ps. 21-22) or the story of Mahmud and his son who changed into stone (ps. 45-51), a girl who learned one hundred magic from an old albino man, the meanest of which in that she transfers the stones of the city behind Kafkuh mountain and transforms its people to fish (p. 75) and fights with an ifrit in a magic war (ps. 76-79).

In the book Pahlavi Narrations belonging to Middle Persian literature some issues are written on the magic properties of dies which expresses Iranians' belief in magic. In the stories of Shahnameh magic has a special place as well; as Fereidoon's awareness of magic and his transformation to dragon (Ferdowsi, volume 1, 1374: 256-268), the old witch in the face of a beauty that Rostam and Esfandyar confront (Ibid, volume 2, 1374: $97-99$ and volume 6: 178-179) or transformation of Ekvan daeva to a beautiful zebra in front of Rostam (Ibid,volume 4, 1374: 303-304) or the magical zebra who misleads Bahram to the castle of a witch (Ibid, volume 8, 1374: 398-402) and transformation of the witch to stone (Ibid, volume 2, 1374: 121). Each of these magical images can also be found in the stories of One Thousand Nights and One Night so the reader can conclude that the roots of some of these magical acts are common with ancient Iranian stories therefore Iranian's belife in magic mentioned in the stories of One Thousand Nights and One Night can be proved through their other old stories.

\section{2. 3. Fire Worshipping}

One of the behaviors Arabs attributed to Iranians during history is fire worshipping. In one of the stories there are a king and his people who worship fire and only the king's child and his nurse worship God. When several warnings from God are received and they do not become believers, they are transformed to stone by God's curse and only the king's son remains (ps. 86-87). Such a curse for Iranian is not found in any of the sources and it is obvious that it is a result of Arabs' thoughts that attributes the curses of the nations mentioned in Qur'an to this Iranian nation; while Iranian believed the fire a symbol of divinity and its flame a reminder of God's light. Another reason that fire was respectable and holy for Iranians was that they believed it to be birth-giving like water and believed that the life of everything depends on it (Yahaghi, 1386:17). On the case of Iranian beliefs to God and His being far from any embodiment Herodotus writes that Persians do not make statue, temple or altar for God even they blame those who do so to be crazy and the reason in my idea is that unlike the Greece they never considered human features for God (Herodotus, 1383: 213); therefore attributing fire-worshipping or curses to Iranians in One Thousand Nights and One Night is not compatible with their beliefs and history.

\section{2. 4. Similar Plots}

Some stories of One Thousand Nights and One Night reminds us of mythical and ancient stories of Iran like the frame story of the book in which Shahryār marries a virgin girl every night and murders her in the morning for three years. This causes the people to leave the city and therefore no other girl remained (p. 8). This reminds us of Zahhak who had two snails on his shoulders and every day fed them with the brains of young men (Ferdowsi, volume 1, 1374: 48).

In another story a father and his son, named Badr Al-Din and Ajib are separated from each other and the boy is questioned that you do not have a known father, accidently they meet each other and they have some feelings but cannot recognize each other and finally the son wards off his father with a stone (ps. 120-125). This story reminds us of the story Rostam and Esfandiyar also the story of Fereidoon and Darab who ask their mothers about their fathers (Ferdowsi, volume one, 1374: 59-60 and volume 2: 178 and volume 6: 360-361).

Separation of prince Abrizeh from his father and his joining Sharkān is also a theme than can be found in some pre-Islamic stories of Iran (ps. 276-285) like Soodabeh who joins Kavoos her husband and leaves his father, King Haman despite the hardships this act brings for her (Ferdowsi, volume 2, 1374:60-137) also her championship in the battlefield and her fight 
against Keshan in the appearance of a man (p. 285) reminds us of the story of Sohrab and Gordafarid in Shahnameh (Ferdowsi, volume 2, 1374: 185).

\section{3. Politics}

In the political section of the tales of One Thousand Nights and One Night the significant position of vizier and his family in the governmental system is obvious as in the frame story of the book we see when no virgin girl remains in the city and Shahryār asks his vizier for a worthy one, he consults this issue with his daughter, Scheherazade, and finally she is the one who returns king's health and saves the girls of country by narrating one thousand and one stories in one thousand and one nights ${ }^{1}$ (p. 8). Another instances of the important role of vizier in One Thousand Nights and One Night include: a mean and malignant vizier who causes the death of king with his false consultations (p. 30) or in the tale of king Sindbād, when the deer flees away from the king's side, this is the vizier who is bold enough to remind the king that he said he is going to kill any person on whose side the deer flees away (p. 31) or these were the viziers who always accompanied the princes to guide and advice them (p. 32). Also in the story of the fisherman and the jinni we see the active presence of the vizier next to the king (ps. 42-43) and finally the vizier who rebels against the king, gains the power and conquers other lands (ps. 64-65) or the vizier who, considering the possession of praised characteristics, is like the king himself and he chooses a wife for the king so that he may have a crown prince (p. 382)

The importance of vizier in pre-Islamic Iran was insofar as the king always selected the wisest person for the position and vizier was authorized to advise the king; the book Advices of Oushnar the wise, is one of these advices. Oushnar, the wise Kianianin vizier, was the vizier of Kay Kāvoos and wrote his advices in fifty six paragraphs (Tafazoli, 1378: 186). In Ferdowsi's Shahnameh sometimes viziers played a determining role in the process of events; Jamasb, the predictor, is the troubleshooter of king Gashtasb; Aristotle is a wise philosopher who prevents Alexander from killing Iranian kings and princes; Ruzbeh accompanies Bahram Gōr in all major tasks; Sharsasb is described as a mediator between the power of God and the king and most famous of all is Buzarjmehr, who is Anushirvan's wisdom and guide in every task (Sarrami, 1378: 820-821).

\section{4. Economics}

The stories of One Thousand Nights and One Night mostly take place in the court with the kings and princes; therefore the setting is aristocratic and the characters of the story have a good financial status. And wherever economic activities are mentioned the status is prosperous, like a merchant who sells one hundred freights of fur, fine silk, and musk over one year with a double benefit (ps. 243-244). In some cases that there is poverty, this poverty can be eliminated because of the good financial status in the society; like the story of the boy who has to pay his father's debts after his death and asks for respite from the creditors and repays a part of the debts per week and finally saves some money for himself (p. 155).

The good financial status described for Iran is compatible with the information from pre-Islamic Iran; because Iran as the empire of the world was very wealthy and features like Silk Road shows Iran's prosperous commerce and good relation with other nations. Herodotus also expresses this interaction between Iran and other nations as follows: when Iranians saw Medians' clothes were more beautiful than their own they started to wear this new cloth and wore Egyptian armors and benefited from all kinds of enjoyments and pleasures which they would see among other nations (Herodotus, 1383:219).

\section{Conclusion}

Based on the presented matters, the images of Iranians are divided into two parts: 1. those compatible with historical and original sources including: loving entertainments (like riding, archery, polo, hunting and drinking), personification of animals and disapprobation of lies under anthropology; belief in daevas and jinnis, belief in magic and having similar plot with Iranian mythical stories under religious and mythical beliefs; emphasis on the important and effective position of vizier and his family in the governmental system under politics; prosperity in commerce in the cities and rare display of poverty under

\footnotetext{
1 The impact of telling stories for going to sleep, its points and types of the tales based on each person's characteristics are mentioned in old medical books (Yousefi, 1380: volume 2: 4)(see: translation of Taqwīm al-sihhah of Ibn Būtlan, 11'th century AD. ). In fact the stories and tales which Scheherazade narrates for Shahryār are organized based on content that will cure Shahryār mentally.
} 
economics; 2. The images not compatible with historical resources and reality of Iranians which was only found under the section anthropology and includes betrayal of spouses which is rarely seen in the Iranian resources and fire worshipping and divine curses which are the result of false attributions of Arabs to Iranians.

\section{References}

Abd Al-Jalil, J. M. (2003). Tarikh-e Adabiyat-e Arab. (Azartash Azarnoosh, Translator). Tehran: Amirkabir publications.

Altabrizi, Abi Zakarya (2009). Sharh Mu'alaqat Al-ashr. (Samir Shams, research). Beirout: Dar Sader.

Ferdowsi, Abolghasem (1995). Shahnameh. (Saeed Hamidian, research), Tehran: Dad publications.

Haririan, Mahmud and colleagues (2001). Tarikh-e Iran Bastan. Volume 1, Tehran, SAMT publications.

Herodotus, (2004). Tarikh-e Herodot. Volume one. (Hadi hedayati, Translator). Tehran: Daneshgah Tehran publications.

Ibn Nadim, Muhammad Ibn Ishaq (1973). Al-fihrist. (Reza Tajadod, Translator). Tehran: Bank Bazrgani Iran publications.

Moura, Jean-Maec. Leurope (1980) Litteraire et Lailleurs. Parisi: Presses universitaires de France.

Nanquette, Laetitia (2011). "Imagology as a Reading Practice for French and Persian Contemporary Prose Texts". Translation of Mojdeh Daghighi. Adabiyat Tatbighi Vizhenameh Farhangestan Journal. Spring. No. 3, pgs. 100-115

Nizami Ganjavi, llyas Ibn-e Yousof (2002). Koliyat, (Vahid Dastgerdi, editor). Tehran: Behzad publications.

Rypka, Jan and Otakar Klima, Jiri Bečka (1991). Tarikh-e Adabiyat Iran. (Keikhosrow Keshavarzi, translator). Tehran: Gutenberg and Javidan Kherad Publications.

Safa, Zabihollah (1999). Tarikh-e Adabiyat-e Iran. (Volume 5, $1^{\text {st }}$ section). Tehran: Ferdows Publications.

Sarrami, Ghadamali (1999). Az Rang-e Gol Ta Ranj-e Khar (Sheklshenasi Dastanhaye Shahnameh). Tehran: Elmi Farhangi Publicayions.

Tafazoli, Ahmad (1999). Tarikh Adabiyat Iran Pish Az Islam. Tehran: Sokhan publications.

Unknown, (1972), The thousand nights and one night. Volume 1. (Translated: Powys Mathers). London and New York: Routledge.

Unknown, (2015). Hezar-o Yek Shab. Volume 1. (Abd Al-latif Tasuji, translator). Tehran: Samir and Gutenberg publications. Yahaghi, Mohamad Jafar (2007). Farhang-e Asatir va Dastanvaareh-ha Dar Adabiayt-e Farsi. Tehran: Farhang-e Moaser publications.

Yousofi, Gholam Hossein (2002). Didari Ba Ahl-e Ghalam. Volume 2. Tehran: Elmi publications. 